\title{
次世代電池を備えた軽量電動アシストトライサイクルの環境評価と導入効果*
}

\section{Environmental Evaluation and Effectiveness of Lightweight Electric-Assist Tricycle Made of Composite Materials with Next-Generation Batteries}

\author{
Naoki MARUYAMA ${ }^{* 1}$ and Mitsuru TAMADA \\ ${ }^{* 1}$ Mie University, Department of Mechanical Engineering \\ 1577 Kurimamachiya-cho, Tsu, Mie 514-8507, Japan
}

\begin{abstract}
Life cycle environmental evaluation of a new lightweight electric-assist tricycle has been discussed in terms of materials supply, production, use and the recycling/disposal stages. The effectiveness of such a novel tricycle is compared with existing transportation from the viewpoint of environmental impact. In the life cycle environmental evaluation, photovoltaic and in-vehicle fuel cell power generations are applied as an energy source for the electric-assist tricycle. Its transportation by light truck, passenger car and the well-known two-wheel electric-assist bicycle is discussed here for comparison. The environmental impact of the electric-assist tricycle, given its photovoltaic power supply, has a minimal environmental impact. The purchased electricity supply and in-vehicle fuel cell supply gradually greatly increased. The material supply and production stages of the electric-assist tricycle account for a large proportion of the overall environmental impact. In addition, the new electric-assist tricycle and other transport means were compared in terms of environmental impact. The factors affecting the environmental impact of each type of transportation device were shown. Then the optimum transport means is proposed suitable for the loadage and the time required in terms of environmental impact. As a result, our novel lightweight electric-assist tricycle was found to be effective for short-distance transport of a small amount of materials, as in a factory or for local transportation.
\end{abstract}

Key Words: Renewable Energy, Global Warming, Greenhouse Effect, Environmental Engineering, LCA, Environmental Evaluation, Photovoltaic Power, Fuel Cell, Electric-Assist Tricycle, Battery

\section{1. 緒言}

近年，地球温暖化といった地球環境問題の深刻化により，社会全体で低炭素社会への転換が進められている. 2009 年には, COP15（第 15 回気候変動枠組条約締約国会議）において，日本は 2020 年までに温室効果ガス排出 量を 1990 年比で $25 \%$ 削減する目標を掲げた。このように, 温室効果ガスの削減は重要な課題となっていること が再確認された。 とくに，運輸部門では我が国の $\mathrm{CO}_{2}$ 排出量の $20 \%$ を占めており，その削減対策を講じることは 温室効果ガスの削減に不可欠である. 2002 年に策定された地球温暖化対策推進大網では，車両燃費の向上，物流 の高効率化 ${ }^{(1)}$ ，クリーンエネルギーの利用が方策として掲げられ，国土交通省では，運輸部門における地球温暖 化対策の 1 つとして自転車利用の環境整備が推進されている.

現在クリーンエネルギーについて，太陽電池や燃料電池の利用が注目されている．太陽電池では，工場や住宅 の屋根への設置に加え, 換気システムの電源として自動車の屋根への設置, 電動アシスト自転車の充電用として 駐輪場に設置するなど，その用途は拡大している(2)．とくに，太陽電池の原材料であるシリコンの使用量が少な く, コスト削減や製造時の環境負荷の低減が期待されている薄膜アモルファスシリコン型太陽電池が注目されて いる(3). 燃料電池では, 携帯機器に用いるモバイル用燃料電池や, 自動車などの車両に搭載することができる車

\footnotetext{
* 原稿受付 2011 年 1 月 6 日

*1 正員, 三重大学大学院工学研究科機械工学専攻（一514-8507 三重県津市栗真町屋町 1577）

*2 学生員, 三重大学大学院工学研究科機械工学専攻

E-mail: maruyama.naoki@mie-u.ac.jp
} 
載型燃料電池の開発が進められている(4). また，クリーンエネルギー利用の技術開発が行われると同時に，現在 では未来型の輸送車両として, 省エネルギーや交通渋滞の解消を目的とした軽量で小型の ULV（超軽量小型自動 車) の研究開発が進められている(5)(6).

このような背景から, 事業所内や市街地の短距離輸送の車両として, 太陽電池充電ポートと車載型燃料電池を 備え, 車体に高強度で軽量な CFRP (炭素繊維) ${ }^{(7)}$ を使用した軽量電動アシストトライサイクルが開発された ${ }^{(8)}$. 軽量電動アシストトライサイクルは，太陽電池と車載型燃料電池で発電した電力で走行し，発電時には温室効果 ガスを排出しない. しかし，車体や太陽電池，燃料電池の材料調達から製造，廃棄に至るまでのライフサイクル にわたる環境性は検討されておらず, 実用化に向けてライフサイクルを通した環境性の検証が求められている. また, 軽量電動アシストトライサイクルはカートを牽引して荷物の輸送が可能であり, 例えば工場敷地内での少 量短距離輸送に導入した場合, 既存の輸送車両である軽トラックや乗用車と比較して, 環境負荷の観点での導入 効果が期待できるものの，その効果は十分に分析されていない，一方，環境負荷低減には，その対策費用も密接 に関係することからライフサイクルコストの評価も重要であるが，まずはライフサイクル環境負荷を定量的に示 すことで環境負荷低減のための課題を明確にすることが必要である. そのため本研究では, 軽量電動アシストト ライサイクル導入の有効性評価を目的に, ライフサイクルの二酸化炭素等価排出量を算出し, 環境負荷の観点で の導入効果を既存の輸送車両と比較して評価する. また, 種々の輸送車両で任意の荷物を運搬する場合の単位荷 重単位距離あたりの二酸化炭素等価排出量を算出すると共に, 荷物に適した運搬方法選定手法を提案する.

\section{記 号}

$\begin{array}{ll}a & \text { 加速度, } \mathrm{m} / \mathrm{s}^{2} \\ D & \text { 耐用期間総走行距離, } \mathrm{km} \\ E & \text { 供給電力量, } \mathrm{kWh} \\ G & \text { 二酸化炭素等価排出量, } \mathrm{kg}-\mathrm{CO}_{2} \mathrm{eq} \\ I & \text { 単位荷重単位距離あたりの二酸化炭素等価排出量, } \mathrm{kg}-\mathrm{CO}_{2} \mathrm{eq} /(\mathrm{kg} \cdot \mathrm{km}) \\ L & \text { 電力量あたり二酸化炭素等価排出量, } \mathrm{kg}-\mathrm{CO}_{2} \mathrm{eq} / \mathrm{kWh} \\ M & \text { 荷物質量, } \mathrm{kg} \\ n & \text { 運搬回数 } \\ P & \text { 消費電力, } \mathrm{kW} \\ V & \text { 車速, } \mathrm{km} / \mathrm{h}\end{array}$

$\begin{array}{ll}\text { 添え字 } & \\ P V & \text { 太陽電池 } \\ F C & \text { 燃料電池 } \\ \text { gen } & \text { 発電 } \\ \text { elec } & \text { 電力 } \\ \text { total } & \text { 耐用期間の積算値 } \\ \text { Cs } & \text { 定常時 } \\ \text { load } & \text { 積載 } \\ \text { trans } & \text { 運搬 }\end{array}$

\section{2. 軽量電動アシストトライサイクル}

本研究で対象とした軽量電動アシストトライサイクルは, 工場敷地内での少量荷物運搬を可能とするカートを 後部に接続できる車両で, 車両への充電は, 家庭用 $\mathrm{AC} 100 \mathrm{~V}$ に加え, 車載型燃料電池または太陽電池充電ポート により行うことができる. 図 1 に荷物運搬用カーゴを備えた車両とカーゴに搭載された車載型燃料電池を, 図 2 に太陽電池充電ポートを示寸. また, 表 1 に各々の仕様を示す. 車両には Li-ion 2 次バッテリが 2 個搭載されて 
おり, 走行時は 1 個ずつ切り替えて使用される. 車載型燃料電池の出力は $0.28 \mathrm{~kW}$ で水素吸蔵合金による燃料夕 ンクが備えられており，走行時に車載バッテリへ充電できる．車載バッテリへの充電は， 2 個搭載されているい ずれかのバッテリ残量が少なくなると燃料電池システムが稼働し，満充電されるまで連続して行われる．この充 電が， 2 個の車載バッテリに対して交互に行われる. 一方, 太陽電池により発電された電力は, 一旦, 併設され る鉛 2 次バッテリに蓄電される.太陽電池から鉛 2 次バッテリへの充電は, 鉛バッテリの残量をモニタリングし ながら行われ，過充電にならないように余剩分は放電される．車両への充電は，車両駐輪時に鉛 2 次バッテリか ら DC/ACインバータと車載充電器を介して 2 個の Li-ion バッテリに充電される.

表 2 に, 運転者の漕ぐ力と車両のアシスト力の比を示す. 運転者の漕ぐ力に対してアシスト力が変化し, $24 \mathrm{~km} / \mathrm{h}$ 以上ではアシストされない. これは，一般的な電動アシスト自転車と同じ設定である ${ }^{(9)}$.

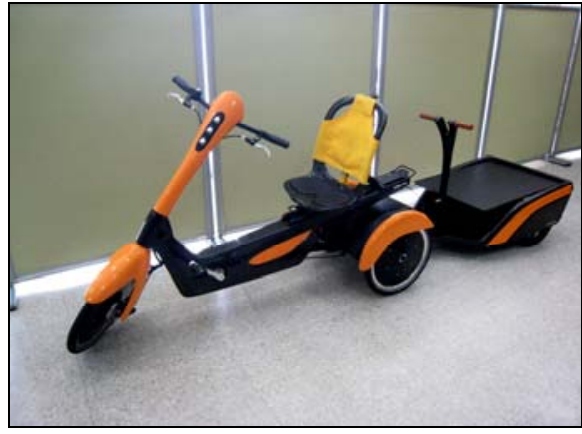

(a) Lightweight electric-assist tricycle

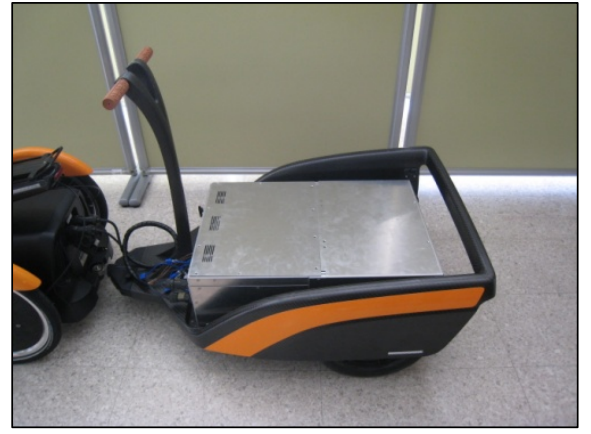

(b) Fuel cell

Fig. 1 Lightweight electric-assist tricycle

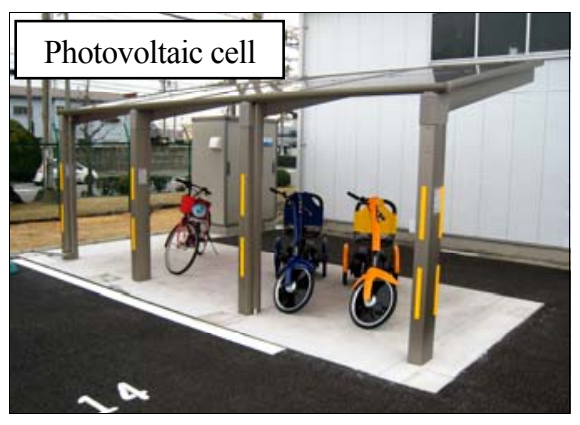

Fig. 2 Photovoltaic cell charge port

Table 1 System specification

\begin{tabular}{|l|l|c|}
\hline \multirow{5}{*}{ Lightweight electric-assist tricycle } & Main material of frame & Carbon composite material \\
& Motor output & $0.25 \mathrm{~kW}$ \\
& Mass of electric-assist tricycle & $37 \mathrm{~kg}$ \\
& Mass of cart & $15 \mathrm{~kg}$ \\
& Maximum loadage of cart & $50 \mathrm{~kg}$ \\
& Secondary battery & $25.9 \mathrm{~V}, 6 \mathrm{Ah} \times 2$ \\
\hline \multirow{5}{*}{ Photovoltaic cell charge port } & Type & Amorphous silicon \\
& Out put & $0.68 \mathrm{~kW}$ \\
& Secondary battery & $12 \mathrm{~V}, 250 \mathrm{Ah} \times 2$ \\
\hline \multirow{5}{*}{ Fuel cell system } & Type & PEFC \\
& Fuel & $\mathrm{H}_{2}$ (Hydrogen storming metal alloy) \\
& Mass & $50 \mathrm{~kg}$ \\
& Out put & $0.28 \mathrm{~kW}$ \\
& Secondary battery & $12 \mathrm{~V}, 16 \mathrm{Ah} \times 1$ \\
\hline
\end{tabular}


Table 2 Assistance ratio to the running speed of an electric-assist tricycle

\begin{tabular}{|c|c|}
\hline Speed & Treading power : Assistance power \\
\hline $0<v \leq 10$ & $1: 2$ \\
\hline $10<v \leq 24$ & $1: 2 \times(24-v) / 14$ \\
\hline $24<v$ & $1: 0$ \\
\hline
\end{tabular}

\section{3. 軽量電動アシストトライサイクルの環境評価}

\section{$3 \cdot 1$ LCA の調査範囲の設定}

軽量電動アシストトライサイクルのライフサイクルの環境負荷を算出するにあたり, 本研究では, 温室効果ガ ス中の $\mathrm{CO}_{2}, \mathrm{CH}_{4}, \mathrm{~N}_{2} \mathrm{O}$ および $\mathrm{SF}_{6}$ の各排出量に着目した. また, GWP (Global Warming Potential) ${ }^{(10) を}$ 用いてこ れらを二酸化炭素等価排出量に換算した. 図 3 に軽量電動アシストトライサイクルの評価範囲を示す.評価範囲 は, 軽量電動アシストトライサイクルの材料調達から製造, 運用およびリサイクル・廃棄である. 太陽電池充電 ポートと車載型燃料電池による充電の環境負荷については, 個々に環境負荷を算出し, 評価車両の運用段階での 環境負荷に計上した.

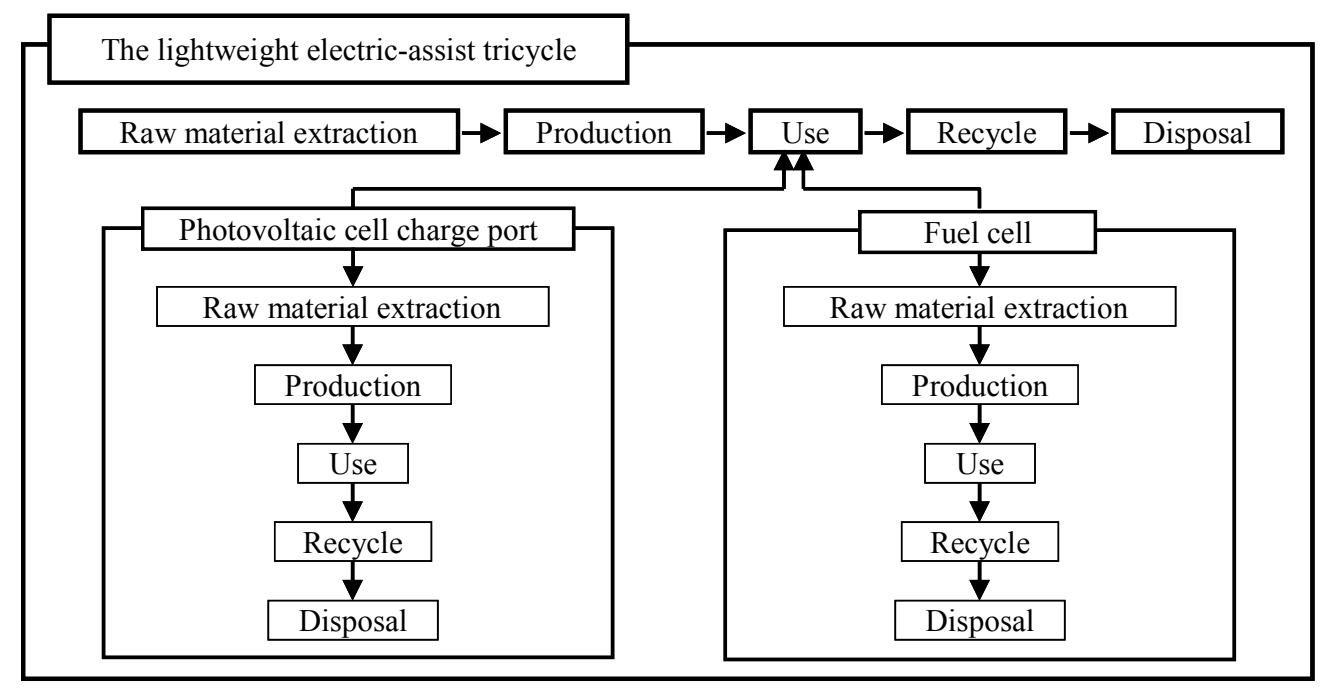

Fig. 3 System boundary for environmental evaluation

\section{$3 \cdot 2$ 材料調達 · 製造の環境負荷算出}

軽量電動アシストトライサイクルの材料調達の環境負荷については, 車体とカートの構成材料から, SimaPro 7.1 と ecoinvent 2.1 を用いて, 温室効果ガス排出量を算出した. 表 3 に主な車体構成材料と温室効果ガス排出量を示 す．製造に関しては，車体とカート製造時の主たるエネルギー消費である CFRP の切り出しと成型に要する消費 電力量を測定し, ecoinvent 2.1 と環境省, 経済産業省の温室効果ガス総排出量算定方法ガイドライン(11)を用いて 温室効果ガス排出量を算出した．表 4 に製造時の消費電力による温室効果ガス排出量を示す.

Table 3 Greenhouse gas emission of principal raw materials of lightweight electric-assist tricycle

\begin{tabular}{|c|c|c|c|c|c|c|c|}
\hline No. & Material & $\begin{array}{c}\text { Mass } \\
{[\mathrm{kg}]}\end{array}$ & $\begin{array}{c}\mathrm{CO}_{2} \text { emission } \\
{\left[\mathrm{kg}-\mathrm{CO}_{2}\right]}\end{array}$ & $\begin{array}{c}\mathrm{CH}_{4} \text { emission } \\
{\left[\mathrm{kg}-\mathrm{CH}_{4}\right]}\end{array}$ & $\begin{array}{c}\mathrm{N}_{2} \mathrm{O} \text { emission } \\
{\left[\mathrm{kg}-\mathrm{N}_{2} \mathrm{O}\right]}\end{array}$ & $\begin{array}{c}\mathrm{SF}_{6} \text { emission } \\
{\left[\mathrm{kg}-\mathrm{SF}_{6}\right]}\end{array}$ & Reference \\
\hline 1 & Aluminum & $1.2 \mathrm{E}+01$ & $9.8 \mathrm{E}+01$ & $1.9 \mathrm{E}-01$ & $3.8 \mathrm{E}-04$ & 0 & SimaPro 7.1 \\
\hline 2 & Li-ion battery & $3.1 \mathrm{E}+00$ & $2.3 \mathrm{E}+02$ & $7.4 \mathrm{E}-01$ & $3.7 \mathrm{E}-03$ & $1.7 \mathrm{E}-05$ & ecoinvent 2.1 \\
\hline 3 & Carbon fiber & $1.5 \mathrm{E}+01$ & $1.8 \mathrm{E}+02$ & $1.8 \mathrm{E}-01$ & 0 & 0 & SimaPro 7.1 \\
\hline 4 & Iron & $1.3 \mathrm{E}+01$ & $2.3 \mathrm{E}+01$ & $6.2 \mathrm{E}-03$ & $9.3 \mathrm{E}-06$ & $3.7 \mathrm{E}-10$ & SimaPro 7.1 \\
\hline
\end{tabular}


Table 4 Greenhouse gas emission of electricity in production process

\begin{tabular}{|c|c|c|c|c|c|c|}
\hline No. & Energy & {$[\mathrm{kWh}]$} & $\begin{array}{c}\mathrm{CO}_{2} \text { emission } \\
{\left[\mathrm{kg}-\mathrm{CO}_{2}\right]}\end{array}$ & $\begin{array}{c}\mathrm{CH}_{4} \text { emission } \\
{\left[\mathrm{kg}-\mathrm{CH}_{4}\right]}\end{array}$ & $\begin{array}{c}\mathrm{N}_{2} \mathrm{O} \text { emission } \\
{\left[\mathrm{kg}-\mathrm{N}_{2} \mathrm{O}\right]}\end{array}$ & $\left.\begin{array}{c}\mathrm{SF}_{6} \text { emission } \\
{[\mathrm{kg}-\mathrm{SF}}\end{array}\right]$ \\
\hline 1 & Commercial electricity & $3.4 \mathrm{E}+01$ & $1.9 \mathrm{E}+01$ & $2.1 \mathrm{E}-02$ & $3.6 \mathrm{E}-04$ & $4.3 \mathrm{E}-08$ \\
\hline
\end{tabular}

\section{$3 \cdot 3$ 運用の環境負荷算出}

軽量電動アシストトライサイクルの運用の環境負荷については，車両走行時に消費する電力量から温室効果ガ ス排出量を算出した. 電力量あたりの環境負荷は, 図 3 にも示されるように発電システムの材料調達から製造, 運用，リサイクル・廃棄にわたる環境負荷を耐用期間の総供給電力量で除したもので，太陽電池充電ポートと車 載型燃料電池それぞれに関して以下の式で表される.

$$
\begin{gathered}
L_{P V, \text { elec }}=\frac{G_{P V, \text { total }}}{E_{P V, \text { total }}} \\
L_{F C, \text { elec }}=\frac{G_{F C, \text { total }}}{E_{F C, \text { total }}}
\end{gathered}
$$

太陽電池充電ポートの環境負荷は, 太陽電池パネルおよび充放電制御機器に分類して算出した. 太陽電池パネ ルに関しては, 発電出力をもとに太陽電池の材料調達から廃棄に至るまでの環境負荷を算出した. 充放電制御機 器に関しては, 部材を計量し, 各部材の材料調達から廃棄に至るまでの環境負荷を算出した. 太陽電池充電ポー トの耐用期間は 10 年間と設定し, 太陽電池充電ポートの総供給電力量は, 予測される年間発電電力量と供給電力 量の実測值から算出した.

車載型燃料電池の環境負荷は, 燃料電池システムと水素燃料に分類して算出した. 燃料電池システムに関して は, 発電出力をもとに材料調達から廃棄に至るまでの環境負荷を算出した. 燃料電池システムの各機器を構成す る部材の材料調達から廃棄に至るまでの環境負荷を算出することが望ましいが，本研究では，燃料電池システム として取扱い, ecoinvent 2.1 搭載のシステムとしての材料調達・製造およびリサイクル・廃棄のインベントリに 基づいて評価した．水素燃料に関しては，発電時の水素消費量を実測し，消費量から環境負荷を算出した，燃料 電池システムの耐用期間は 5,000 時間と設定した. 車載型燃料電池の総供給電力量は実測值から算出した. 本研 究で用いた燃料電池システムの出力端での発電効率 ${ }^{(12)}$ は, 水素消費量と発電電力量から算出したところ $16.8 \%$ あった。

車両走行時の消費電力は, 表 5 に示される車速, 加減速およびカートへの積載量を変化させた走行パターンを 設定して実測した。車両については，車両のみの場合，車両にカートを接続して荷物を積載しない場合，車両に カートを接続して $50 \mathrm{~kg} の$ 荷物を積載した場合を設定した. 運転者と車載する測定器の質量は $65 \mathrm{~kg}$ である. 車速 は, 定常走行時に $10 \mathrm{~km} / \mathrm{h}, 15 \mathrm{~km} / \mathrm{h}$ で走行する場合と $5 \sim 20 \mathrm{~km} / \mathrm{h}$ まで速度を変化させて走行するパターンを設定 した. 加減速については, 運転者が特に意識をしない加速, 定常走行, 停車の走行パターンと, 急加速, 定常走 行, 急停車を繰り返す走行パターンを設定した.

車速と走行距離の測定には，車輪にマグネット式回転計を取り付け，車輪の回転数と周長から算出した．消費 電力については，搭載されるバッテリの電圧と消費される電流を測定して算出した．図４に示すように，これら をデータロガーで同時に記録することにより，車速および加減速に関する消費電力を算出した.

図 5 に，実験結果の一例として表 5 に示される車速 $v_{c s}=15 \mathrm{~km} / \mathrm{h}$ の定常時の実験条件(iii-a), (iii-b), (iii-c)に関 する車速と消費電力を示す．消費電力は，モータ駆動電力と制御機器の消費電力の和である．正の值は電力の消 費を示し, 負の值は減速時の回生によるバッテリへの充電を示している. アシストカは運転者の漕ぐ力に依存す るため，車速の関数として表すことができない． 
Table 5 Running pattern of lightweight electric-assist tricycle

\begin{tabular}{|c|c|c|c|c|c|c|}
\hline \multirow[t]{3}{*}{ Index } & & (i) & (ii) & (iii) & (iv) & \multirow{3}{*}{$\begin{array}{c}(\mathrm{v}) \\
5-20 \mathrm{~km} / \mathrm{h} \\
\text { Sudden } \\
\text { acceleration } \\
\downarrow \\
\text { Constant speed } \\
\downarrow \\
\text { Sudden stop } \\
\end{array}$} \\
\hline & Speed & \multicolumn{2}{|c|}{$10 \mathrm{~km} / \mathrm{h}$} & \multicolumn{2}{|c|}{$15 \mathrm{~km} / \mathrm{h}$} & \\
\hline & Pattern & $\begin{array}{c}\text { Acceleration } \\
\downarrow \\
\text { Constant speed } \\
\downarrow \\
\text { Stop }\end{array}$ & $\begin{array}{c}\text { Sudden } \\
\text { acceleration } \\
\downarrow \\
\text { Constant speed } \\
\downarrow \\
\text { Sudden stop } \\
\end{array}$ & $\begin{array}{c}\text { Acceleration } \\
\downarrow \\
\text { Constant speed } \\
\downarrow \\
\text { Stop } \\
\end{array}$ & $\begin{array}{c}\text { Sudden } \\
\text { acceleration } \\
\downarrow \\
\text { Constant speed } \\
\downarrow \\
\text { Sudden stop } \\
\end{array}$ & \\
\hline (a) & Tricycle only & $\bigcirc$ & $\bigcirc$ & $\bigcirc$ & $\bigcirc$ & $\bigcirc$ \\
\hline (b) & $\begin{array}{l}\text { Tricycle with cart } \\
\text { (No load) }\end{array}$ & $\bigcirc$ & $\bigcirc$ & $\bigcirc$ & $\bigcirc$ & $\bigcirc$ \\
\hline (c) & $\begin{array}{l}\text { Tricycle with cart } \\
\text { (50 kg load) }\end{array}$ & $\bigcirc$ & $\bigcirc$ & $\bigcirc$ & $\bigcirc$ & $\bigcirc$ \\
\hline
\end{tabular}

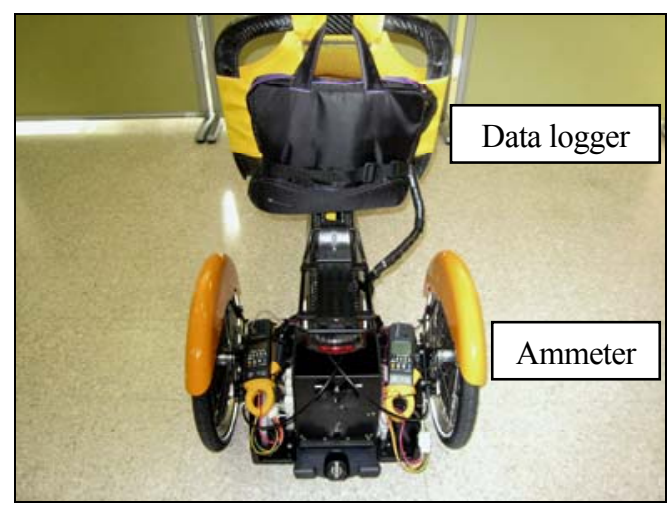

Fig. 4 Experimental equipment of lightweight electric-assist tricycle

図 5 において，車速が $10 \mathrm{~km} / \mathrm{h}$ 以上のとき，車速が速くなるに従って消費電力の最大值が小さくなっている. また, 消費電力はモータの出力 $0.25 \mathrm{~kW}$ に対して大きな值をとっている. 本実験では, $15 \mathrm{~km} / \mathrm{h}$ 近傍での実験例の ために約 $18 \mathrm{~km} / \mathrm{h}$ までのアシストの結果を示しているが，各速度の最大アシスト時の漸近線は，図 5 の破線で示 されるように $v=24 \mathrm{~km} / \mathrm{h}$ で消費電力が 0 となっている.この破線は車両の運行条件により異なるが，これは表 2 の式に示されるように $24 \mathrm{~km} / \mathrm{h}$ でアシスト力が 0 になるためであり，漕ぐ力が大きいと消費電力も大きくなり， その結果勾配が大きくなる，一方，漕ぐ力が小さいと消費電力が小さくなり，勾配が小さくなる.

図 6 に，表 5 に示される実験条件における，車両のみの場合，車両にカートを接続して荷物を積載しない場合 および車両にカートを接続して $50 \mathrm{~kg}$ の荷物を積載した場合の加速度と消費電力の平均值を示す．加速度の正の 值は加速を示し，負值は減速を示している. 電力の正の值は電力の消費を示し，負の值は減速時の回生によるバ ッテリへの充電を示している. 図中に, $P$ と $a$ の関係式を $a<0$ と $a \geq 0$ の領域それぞれに関して示す. いずれの 運行条件においても $a \geq 0$ の領域では，加速度が大きくなるに従って消費電力が大きくなっている．また， $a に$ 対 する $P$ の勾配は $(a)<(b)<(c)$ となり, 車両重量が大きくなるに従ってより多くのエネルギーを消費していることが わかる. $a<0$ の領域では, 減速度が大きくなるに従って, 回生電力が大きくなっている. また, 車両により多く の荷物を積載した場合の方が $a$ に対する $P$ の勾配が大きくなり, 同じ減速度での回生電力が大きくなっている. なお， $P$ と $a$ の関係式において切片が $0 \mathrm{~kW}$ になってない. これは， $a=0 \mathrm{~m} / \mathrm{s}^{2}$ の時には停車している場合と等 速で走行している場合があり，制御機器と等速走行時のモータの消費電力の值が含まれているためである．車両 の条件により切片が異なるのは，車両重量による等速走行時のモータの消費電力の差異であり, 車両重量が大き いと消費電力は大きくなっている.

表 6 に, 軽量電動アシストトライサイクル運用時のエネルギー供給別の温室効果ガス排出量を示す. 温室効果 ガス排出量は, 消費電力量から SimaPro 7.1, ecoinvent 2.1 を用いて算出した. 走行時の消費電力量は, カートへ の積載量を $0 \mathrm{~kg}, 20 \mathrm{~kg}$ および $50 \mathrm{~kg}$ に設定して実測した。車載型燃料電池搭載時は，燃料電池本体の自重のため 
に, カートへの積載量を $0 \mathrm{~kg}$ とした。 ここで, 軽量電動アシストトライサイクルの耐用期間総走行距離を 10,000 $\mathrm{km}$ と設定した.

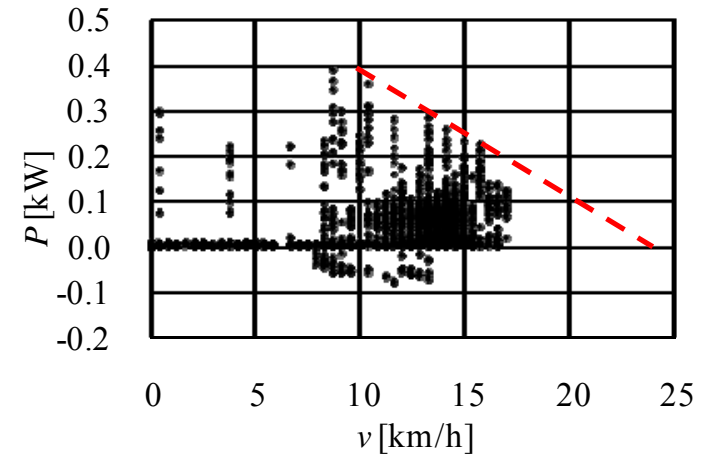

(a) Tricycle only

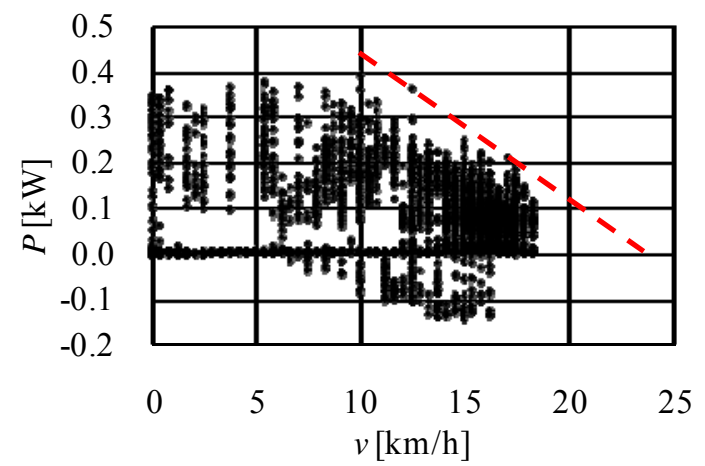

(b) Tricycle with cart (No loadage)

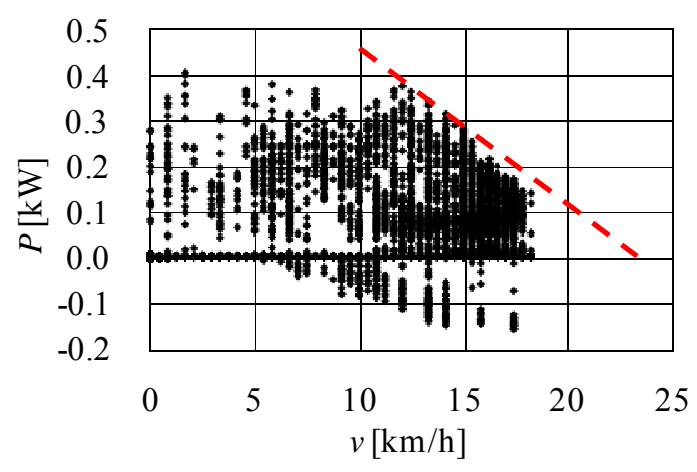

(c) Tricycle with cart (50 kg loadage)

Fig. 5 Power consumption to speed $\left(v_{c s}=15 \mathrm{~km} / \mathrm{h}\right)$

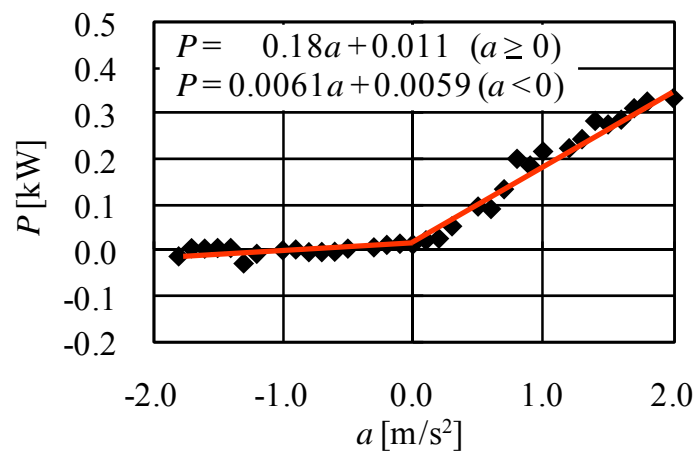

(a) Tricycle only

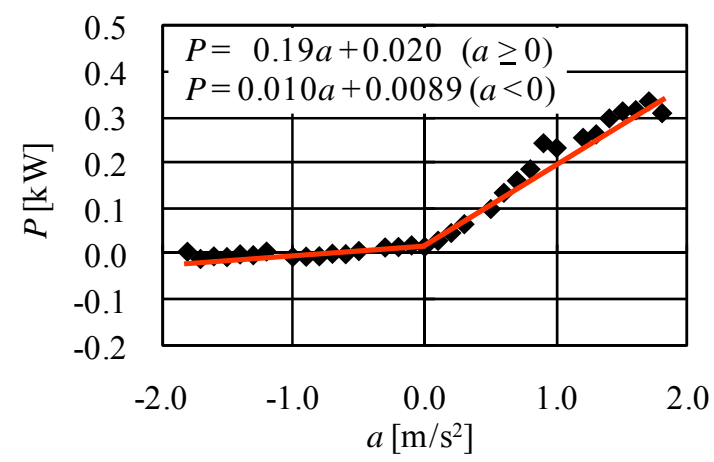

(b) Tricycle with cart (No loadage)

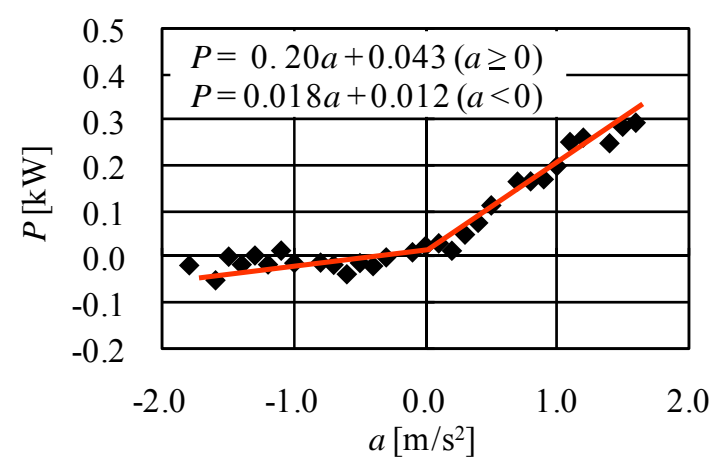

(c) Tricycle with cart (50 kg loadage)

Fig. 6 Average power consumption for acceleration

Table 6 Condition and Greenhouse gas emission of lightweight-electric assist tricycle in use

\begin{tabular}{|c|c|c|c|c|c|c|c|}
\hline Energy supplied & $\begin{array}{c}\text { Electricity } \\
\text { consumption } \\
{[\mathrm{Wh} / \mathrm{km}]}\end{array}$ & $\begin{array}{l}\text { Loadage } \\
{[\mathrm{kg}]}\end{array}$ & $\begin{array}{c}\mathrm{CO}_{2} \text { emission } \\
{\left[\mathrm{kg}-\mathrm{CO}_{2}\right]}\end{array}$ & $\begin{array}{c}\mathrm{CH}_{4} \text { emission } \\
{\left[\mathrm{kg}-\mathrm{CH}_{4}\right]}\end{array}$ & $\begin{array}{c}\mathrm{N}_{2} \mathrm{O} \text { emission } \\
{\left[\mathrm{kg}-\mathrm{N}_{2} \mathrm{O}\right]}\end{array}$ & $\begin{array}{c}\mathrm{SF}_{6} \text { emission } \\
{\left[\mathrm{kg}_{-}-\mathrm{SF}_{6}\right]}\end{array}$ & Reference \\
\hline \multirow{3}{*}{$\begin{array}{l}\text { Photovoltaic cell } \\
\text { charge port }\end{array}$} & 2.6 & 0 & $7.5 \mathrm{E}+00$ & $1.0 \mathrm{E}-02$ & $1.9 \mathrm{E}-04$ & $5.9 \mathrm{E}-07$ & \multirow{3}{*}{$\begin{array}{l}\text { SimaPro } 7.1 \\
\text { ecoinvent } 2.1\end{array}$} \\
\hline & 3.1 & 20 & $8.9 \mathrm{E}+00$ & $1.2 \mathrm{E}-02$ & $2.2 \mathrm{E}-04$ & 7.0E-07 & \\
\hline & 4.1 & 50 & $1.2 \mathrm{E}+01$ & $1.6 \mathrm{E}-02$ & $2.9 \mathrm{E}-04$ & $9.3 \mathrm{E}-07$ & \\
\hline Fuel cell & 4.1 & 0 & $5.6 \mathrm{E}+01$ & $9.7 \mathrm{E}-02$ & $1.9 \mathrm{E}-03$ & $2.7 \mathrm{E}-06$ & ecoinvent 2.1 \\
\hline \multirow{3}{*}{$\begin{array}{l}\text { Commercial } \\
\text { electric power }\end{array}$} & 2.6 & 0 & $1.5 \mathrm{E}+01$ & $1.7 \mathrm{E}-02$ & $2.9 \mathrm{E}-04$ & $3.5 \mathrm{E}-08$ & \multirow{3}{*}{ ecoinvent 2.1} \\
\hline & 3.1 & 20 & $1.8 \mathrm{E}+01$ & $2.1 \mathrm{E}-02$ & $3.5 \mathrm{E}-04$ & $4.1 \mathrm{E}-08$ & \\
\hline & 4.1 & 50 & $2.4 \mathrm{E}+01$ & $2.7 \mathrm{E}-02$ & $4.6 \mathrm{E}-04$ & $5.5 \mathrm{E}-08$ & \\
\hline
\end{tabular}




\section{$3 \cdot 4$ リサイクル・廃棄の環境負荷算出}

軽量電動アシストトライサイクルのリサイクルおよび廃棄については，各構成材料の一般的なリサイクル率と 廃雍率(13)(14)を導入し, SimaPro 7.1 と ecoinvent 2.1 を用いて, その処理における温室効果ガス排出量を算出した. 表 7 は，主要な構成材料のリサイクルと廃棄の温室効果ガス排出量とリサイクル率を示す．また，リサイクルに よる環境負荷は，環境負荷を低減するために負值で示す.

Table 7 Greenhouse gas emission of lightweight-electric assist tricycle in recycle and disposal process

\begin{tabular}{|c|c|c|c|c|c|c|c|c|}
\hline No. & Material & $\begin{array}{c}\text { Weight } \\
{[\mathrm{kg}]}\end{array}$ & $\begin{array}{c}\mathrm{CO}_{2} \text { emission } \\
{\left[\mathrm{kg}-\mathrm{CO}_{2}\right]}\end{array}$ & $\begin{array}{c}\mathrm{CH}_{4} \text { emission } \\
{\left[\mathrm{kg}-\mathrm{CH}_{4}\right]}\end{array}$ & $\begin{array}{c}\mathrm{N}_{2} \mathrm{O} \text { emission } \\
{\left[\mathrm{kg}-\mathrm{N}_{2} \mathrm{O}\right]}\end{array}$ & $\begin{array}{c}\mathrm{SF}_{6} \text { emission } \\
{\left[\mathrm{kg}_{-} \mathrm{SF}_{6}\right]}\end{array}$ & Recycle rate ${ }^{(13)(14)}$ & Reference \\
\hline 1 & Aluminum & $1.2 \mathrm{E}+01$ & $-4.6 \mathrm{E}+01$ & $-1.0 \mathrm{E}-01$ & $-2.5 \mathrm{E}-04$ & 0 & 0.55 & SimaPro 7.1 \\
\hline 2 & Li-ion battery & $3.1 \mathrm{E}+00$ & $1.9 \mathrm{E}+00$ & $1.8 \mathrm{E}-03$ & $1.4 \mathrm{E}-04$ & $5.6 \mathrm{E}-08$ & 0 & ecoinvent 2.1 \\
\hline 3 & Carbon fiber & $1.5 \mathrm{E}+01$ & $2.3 \mathrm{E}+01$ & 5.7E-04 & $3.4 \mathrm{E}-04$ & $6.5 \mathrm{E}-09$ & 0 & ecoinvent 2.1 \\
\hline 4 & Iron & $1.3 \mathrm{E}+01$ & $-7.1 \mathrm{E}+00$ & $-3.7 \mathrm{E}-02$ & $-9.9 \mathrm{E}-06$ & 0 & 0.38 & SimaPro 7.1 \\
\hline
\end{tabular}

\section{$3 \cdot 5$ ライフサイクル環境負荷評価}

軽量電動アシストトライサイクルの材料調達から製造, 運用, リサイクル・廃棄での環境負荷を統合し, GWP を用いて二酸化炭素等価排出量に換算した．表 8 と図 7 に二酸化炭素等価排出量を電力供給方法別に示す. 材料 調達・製造とリサイクル・廃棄の環境負荷に関しては，同じ車両を用いて評価するために，いずれの条件におい ても等しくなっている．本研究で対象とした条件においては，太陽電池充電ポートによる充電が最も環境負荷が 小さく，順に買電供給，車載型然料電池供給と大きくなっている．車載型燃料電池供給に関しては，システムが プロトタイプということもあり，性能が十分発揮されていない点もある．また，軽量電動アシストトライサイク ルの材料調達と製造における環境負荷の割合が大きいことがわかる．これは，車体に搭載されているリチウムイ オンバッテリと，車体フレームを構成する CFRP の材料調達と製造における環境負荷が大きく影響している．こ のため，車体フレームをより低負荷の材料に置き換えることで環境負荷を低減できる．このことから，軽量電動 アシストトライサイクルは，材料調達と製造の環境負荷が全体の環境負荷に対して大きいため，環境負荷を考慮 した材料を選択することの重要性が示唆された.また, 軽量電動アシストトライサイクルの運用時の環境負荷は, 電力供給システムの発電効率の向上ならびにシステムのコンパクト化等による使用材料の削減により，二酸化炭 素等価排出量の低減も期待できる.

Table $8 \quad \mathrm{CO}_{2}$ eq emission of lightweight electric-assist tricycle

\begin{tabular}{|c|c|c|c|c|c|}
\hline Energy supplied & $\begin{array}{l}\text { Loadage } \\
{[\mathrm{kg}]}\end{array}$ & $\begin{array}{c}\text { Raw material extraction and } \\
\text { production }\left[\mathrm{kg}-\mathrm{CO}_{2} \mathrm{eq}\right]\end{array}$ & $\begin{array}{c}\text { Use } \\
{\left[\mathrm{kg}-\mathrm{CO}_{2} \mathrm{eq}\right]}\end{array}$ & $\begin{array}{l}\text { Recycle and disposal } \\
{\left[\mathrm{kg}-\mathrm{CO}_{2} \mathrm{eq}\right]}\end{array}$ & $\begin{array}{c}\text { Total } \\
{\left[\mathrm{kg}-\mathrm{CO}_{2} \mathrm{eq}\right]}\end{array}$ \\
\hline \multirow{3}{*}{$\begin{array}{l}\text { Photovoltaic cell } \\
\text { charge port }\end{array}$} & 0 & \multirow{7}{*}{$6.1 \mathrm{E}+02$} & $7.7 \mathrm{E}+00$ & \multirow{7}{*}{$-7.8 \mathrm{E}+00$} & $6.1 \mathrm{E}+02$ \\
\hline & 20 & & $9.2 \mathrm{E}+00$ & & $6.1 \mathrm{E}+02$ \\
\hline & 50 & & $1.2 \mathrm{E}+01$ & & $6.1 \mathrm{E}+02$ \\
\hline Fuel cell & 0 & & $5.8 \mathrm{E}+01$ & & $6.6 \mathrm{E}+02$ \\
\hline \multirow{3}{*}{$\begin{array}{l}\text { Commercial } \\
\text { electric power }\end{array}$} & 0 & & $1.6 \mathrm{E}+01$ & & $6.2 \mathrm{E}+02$ \\
\hline & 20 & & $1.9 \mathrm{E}+01$ & & $6.2 \mathrm{E}+02$ \\
\hline & 50 & & $2.5 \mathrm{E}+01$ & & $6.3 \mathrm{E}+02$ \\
\hline
\end{tabular}




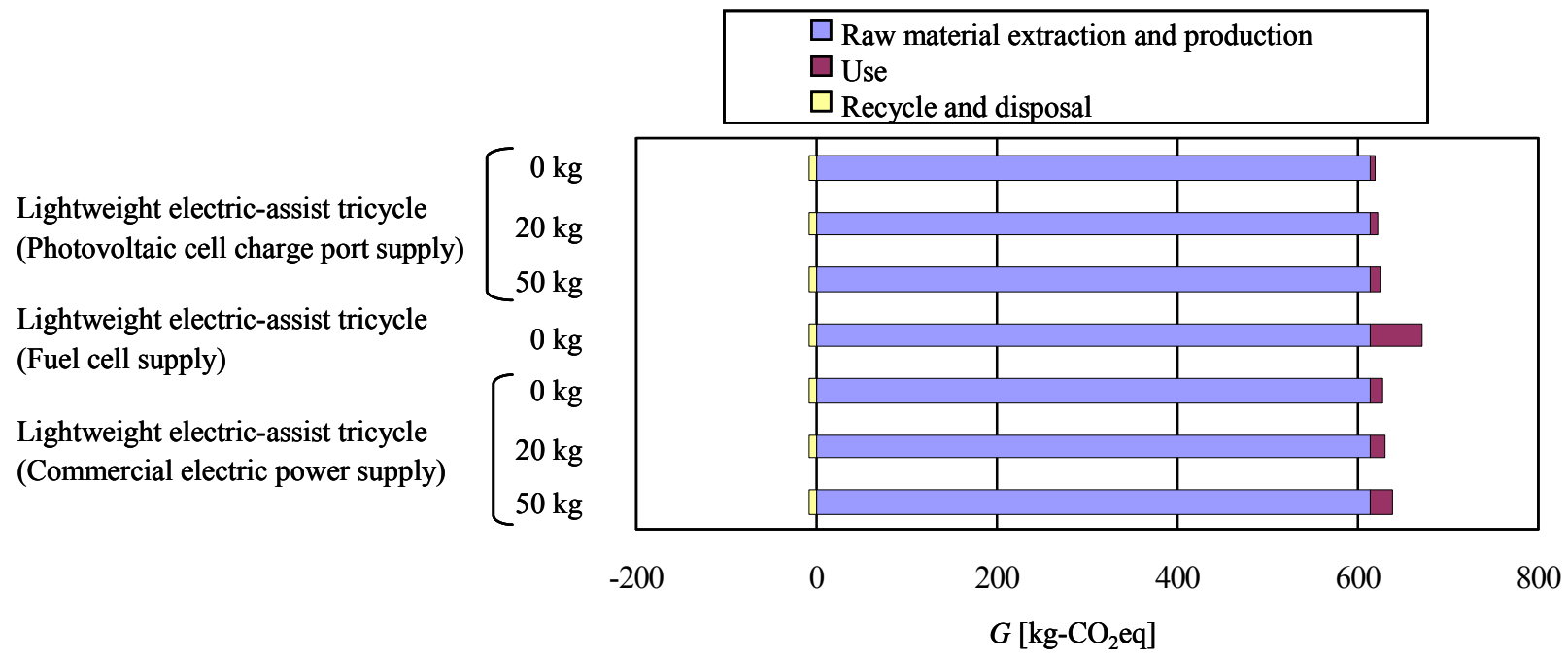

Fig. $7 \mathrm{CO}_{2}$ eq emission of lightweight electric-assist tricycle

\section{4. 軽量電動アシストトライサイクル導入の有効性評価}

\section{$4 \cdot 1$ 比較対象車両}

軽量電動アシストトライサイクルと既存の輸送車両の環境負荷を比較して，軽量電動アシストトライサイクル 導入の有効性を評価する. 本研究では，工場内の人と荷物の輸送を想定し，軽トラック，乗用車，スクーター（原 動機付自転車）および一般的な 2 輪電動アシスト自転車を比較対象とした。これらの輸送車両の設定条件を表 9 に示す．積載量は，最大積載量の約 $30 \%$ に設定した。エネルギー消費に関して，軽量電動アシストトライサイク ルと 2 輪電動アシスト自転車については荷物を積載した状態で実測した。一方，スクーター，軽トラックおよび 自動車に関しては，各車種のカタログを参考に設定した.

Table 9 Evaluation condition of vehicles in life cycle

\begin{tabular}{|c|c|c|c|c|c|}
\hline Vehicle & Energy supplied & $\begin{array}{c}\text { Energy } \\
\text { consumption }\end{array}$ & $\begin{array}{c}\text { Maximum } \\
\text { loadage }[\mathrm{kg}]\end{array}$ & $\begin{array}{c}\text { Assumed } \\
\text { loadage }[\mathrm{kg}]\end{array}$ & $\begin{array}{c}\text { Service life } \\
\text { distance }[\mathrm{km}]\end{array}$ \\
\hline \multirow{3}{*}{$\begin{array}{l}\text { Lightweight } \\
\text { electric-assist tricycle }\end{array}$} & $\begin{array}{c}\text { Photovoltaic cell } \\
\text { charge port }\end{array}$ & $320 \mathrm{~km} / \mathrm{kWh}^{* 1}$ & \multirow{3}{*}{50} & 20 & \multirow{4}{*}{10,000} \\
\hline & Fuel cell & $240 \mathrm{~km} / \mathrm{kWh}^{* 1}$ & & $\begin{array}{c}0 \\
\text { (FC only) }\end{array}$ & \\
\hline & $\begin{array}{l}\text { Commercial } \\
\text { electric power }\end{array}$ & $320 \mathrm{~km} / \mathrm{kWh}^{* 1}$ & & 20 & \\
\hline Electric-assist bicycle & $\begin{array}{l}\text { Commercial } \\
\text { electric power }\end{array}$ & $400 \mathrm{~km} / \mathrm{kWh}^{* 1}$ & 3 & 1 & \\
\hline Scooter (Moped) & Gasoline & $30 \mathrm{~km} / \mathrm{L}^{* 2}$ & 30 & 10 & 20,000 \\
\hline Passenger car & Gasoline & $12 \mathrm{~km} / \mathrm{L}^{* 2}$ & 500 & 200 & \multirow{2}{*}{100,000} \\
\hline Light truck (Small truck) & Gasoline & $15 \mathrm{~km} / \mathrm{L}^{* 2}$ & 350 & 100 & \\
\hline
\end{tabular}

*1 Measured value

*2 Commercial-type vehicle

\section{$4 \cdot 2$ 各輸送車両のライフサイクル環境負荷評価}

各輸送車両のライフサイクルの環境負荷を算出した。評価範囲は，軽量電動アシストトライサイクルと同様に 材料調達・製造，運用，リサイクル・廃棄である．環境負荷は温室効果ガス中の $\mathrm{CO}_{2}, \mathrm{CH}_{4}, \mathrm{~N}_{2} \mathrm{O}$ および $\mathrm{SF}_{6}$ の 各排出量を SimaPro 7.1 と ecoinvent 2.1 を用いて算出した. また，GWP を用いて二酸化炭素等価排出量に換算し た. 軽トラックに関する環境負荷は, 3.5 トン積みトラックの值に基づいて, 車両重量と積載量を考慮して見積っ た. 
表 10 と図 8 に, 各輸送車両のライフサイクルにおける二酸化炭素等価排出量を示す.本研究で用いた条件にお いては, 2 輪電動アシスト自転車の環境負荷が最も小さく, 乗用車の環境負荷が最も大きくなっている.これは, 乗用車の耐用期間総走行距離が長く, 運用時のエネルギー消費量が非常に大きくなっているためである. 同様に, 耐用期間総走行距離の長い軽トラックやスクーターもまた運用時の環境負荷が大きくなっている.このため，乗 用車，軽トラック，スクーターでは，然費向上によって運用時の消費エネルギーを削減することにより，環境負 荷の低減が期待できる。一方，耐用期間総走行距離の短い 2 輪電動アシスト自転車や軽量電動アシストトライサ イクルの運用時の環境負荷は小さく，材料調達と製造の環境負荷の占める割合が大きいことがわかる.

Table $10 \quad \mathrm{CO}_{2}$ eq emission of each vehicle

\begin{tabular}{|c|c|c|c|c|c|c|}
\hline Vehicle & Energy supplied & $\begin{array}{c}\text { Loadage } \\
{[\mathrm{kg}]}\end{array}$ & $\begin{array}{c}\text { Raw material extraction } \\
\text { and production } \\
{\left[\mathrm{kg}-\mathrm{CO}_{2} \mathrm{eq}\right]}\end{array}$ & $\begin{array}{c}\text { Use } \\
{\left[\mathrm{kg}-\mathrm{CO}_{2} \mathrm{eq}\right]}\end{array}$ & $\begin{array}{l}\text { Recycle and disposal } \\
{\left[\mathrm{kg}-\mathrm{CO}_{2} \mathrm{eq}\right]}\end{array}$ & $\begin{array}{c}\text { Total } \\
{\left[\mathrm{kg}-\mathrm{CO}_{2} \mathrm{eq}\right]}\end{array}$ \\
\hline \multirow{3}{*}{$\begin{array}{l}\text { Lightweight } \\
\text { electric-assist } \\
\text { tricycle }\end{array}$} & $\begin{array}{c}\text { Photovoltaic cell } \\
\text { charge port }\end{array}$ & 20 & \multirow{3}{*}{$6.1 \mathrm{E}+02$} & $9.2 \mathrm{E}+00$ & \multirow{3}{*}{$-7.8 \mathrm{E}+00$} & $6.1 \mathrm{E}+02$ \\
\hline & Fuel cell & $\begin{array}{c}0 \\
\text { (FC only) }\end{array}$ & & $5.8 \mathrm{E}+01$ & & $6.6 \mathrm{E}+02$ \\
\hline & $\begin{array}{l}\text { Commercial } \\
\text { electric power }\end{array}$ & 20 & & $1.9 \mathrm{E}+01$ & & $6.2 \mathrm{E}+02$ \\
\hline $\begin{array}{c}\text { Electric-assist } \\
\text { bicycle }\end{array}$ & $\begin{array}{l}\text { Commercial } \\
\text { electric power }\end{array}$ & 1 & $1.9 \mathrm{E}+02$ & $1.4 \mathrm{E}+01$ & $-4.7 \mathrm{E}+00$ & $2.0 \mathrm{E}+02$ \\
\hline $\begin{array}{c}\text { Scooter } \\
\text { (Moped) }\end{array}$ & Gasoline & 10 & $3.3 \mathrm{E}+02$ & $1.3 \mathrm{E}+03$ & $6.8 \mathrm{E}+01$ & $1.7 \mathrm{E}+03$ \\
\hline Passenger car & Gasoline & 200 & $4.1 \mathrm{E}+03$ & $2.3 \mathrm{E}+04$ & $3.8 \mathrm{E}+02$ & $2.7 \mathrm{E}+04$ \\
\hline $\begin{array}{l}\text { Light truck } \\
\text { (Small truck) }\end{array}$ & Gasoline & 100 & $1.9 \mathrm{E}+03$ & $1.8 \mathrm{E}+04$ & $2.6 \mathrm{E}+01$ & $2.0 \mathrm{E}+04$ \\
\hline
\end{tabular}

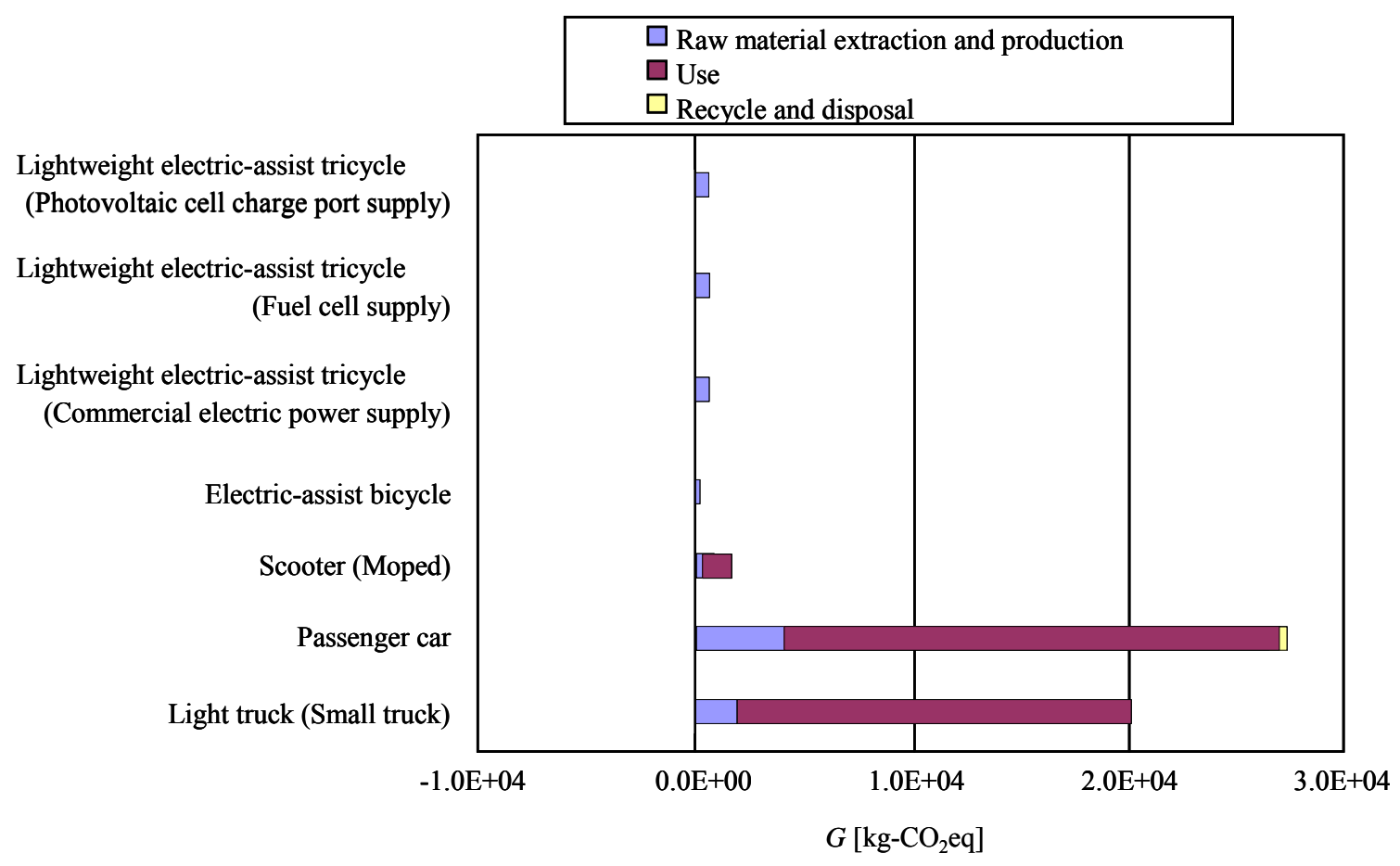

Fig. $8 \quad \mathrm{CO}_{2}$ eq emission of each vehicle 


\section{$4 \cdot 3$ 最適運搬車両選定手法の提案}

各輸送車両の環境負荷を評価する場合，輸送車両により最大積載量や，耐用期間総走行距離が異なる．このた め, 単位荷重単位距離あたりのライフサイクル評価を行った。単位荷重単位距離あたり 環境負荷は, $1 \mathrm{~kg} の$ 荷物 を $1 \mathrm{~km}$ 運搬するための二酸化炭素等価排出量で，車両のライフサイクルの二酸化炭素等価排出量を耐用期間総 走行距離と積載量で除した值で求められる. 運搬時の積載量と二酸化炭素等価排出量の関係は式(3)で表され，そ の結果を図 9 に示す. 軽量電動アシストトライサイクルに関しては, ライフサイクルの環境負荷が最も小さい太 陽電池充電ポート供給で評価した.

$$
I \times M_{\text {load }}=\frac{G_{\text {total }}}{D}
$$

従来，輸送車両等の環境負荷を評価する場合，ある運行条件における負荷を算出する場合が多い．図 9 を用い ると，例えば $100 \mathrm{~kg}$ の荷物を運搬する場合，一度に運搬することを望めば，図 9 の破線 $\mathrm{a}$ に示されるように軽卜 ラックによる運搬が適している. しかしながら, 運搬回数や所要時間に拘らない場合, 図 9 の破線 $\mathrm{b}$ に示される ように，軽量電動アシストトライサイクルを用いて一度に $30 \mathrm{~kg}$ 以上の荷物を積載して運搬すれば，単位荷重単 位距離あたりの二酸化炭素等価排出量を低減することができる.すなわち，式(3)の導入により，二酸化炭素等価 排出量のより低い輸送車両を選定することができる.

一方，ユーザ視点に立てば，運搬する荷物に対して適切な運搬車両と運搬回数を選定することが望まれる．す なわち, 例えば $100 \mathrm{~kg}$ の荷物を運搬する場合, 図 9 を用いれば軽量電動アシストトライサイクルを用いて複数回 運搬することで単位荷重単位距離あたりの二酸化炭素等価排出量を低減することはできるが，その適切な荷重の 組み合わせを提示することができない，そこで，式(4)を用いて，最適運搬車両選定手法を提案する.

$$
I \times \frac{M_{\text {trans }}}{n}=\frac{G_{\text {total }}}{D}
$$

式(4)は運搬回数を用いて運搬量と二酸化炭素等価排出量の関係を示しており，その結果を図 10 に示す．運搬 回数とは, 全ての荷物を運搬するために必要な運搬回数の最小值である. 例えば $100 \mathrm{~kg}$ の荷物を運搬する場合, 図 10 の破線aによれば軽量電動アシストトライサイクルを用いることで単位荷重単位距離あたりの二酸化炭素等 価排出量を最も小さくすることができる. この場合, 運搬回数は 2 となり, 軽量電動アシストトライサイクルに $50 \mathrm{~kg}$ の荷物を積載して2回運搬することが望ましいことが読み取れる. 同様に, $600 \mathrm{~kg}$ の荷物を運搬する場合は, 図 10 の破線 $\mathrm{b}$ によれば, 軽トラックを用いて 2 回運搬する場合が最も環境負荷を低減できる運搬方法であること がわかる。 

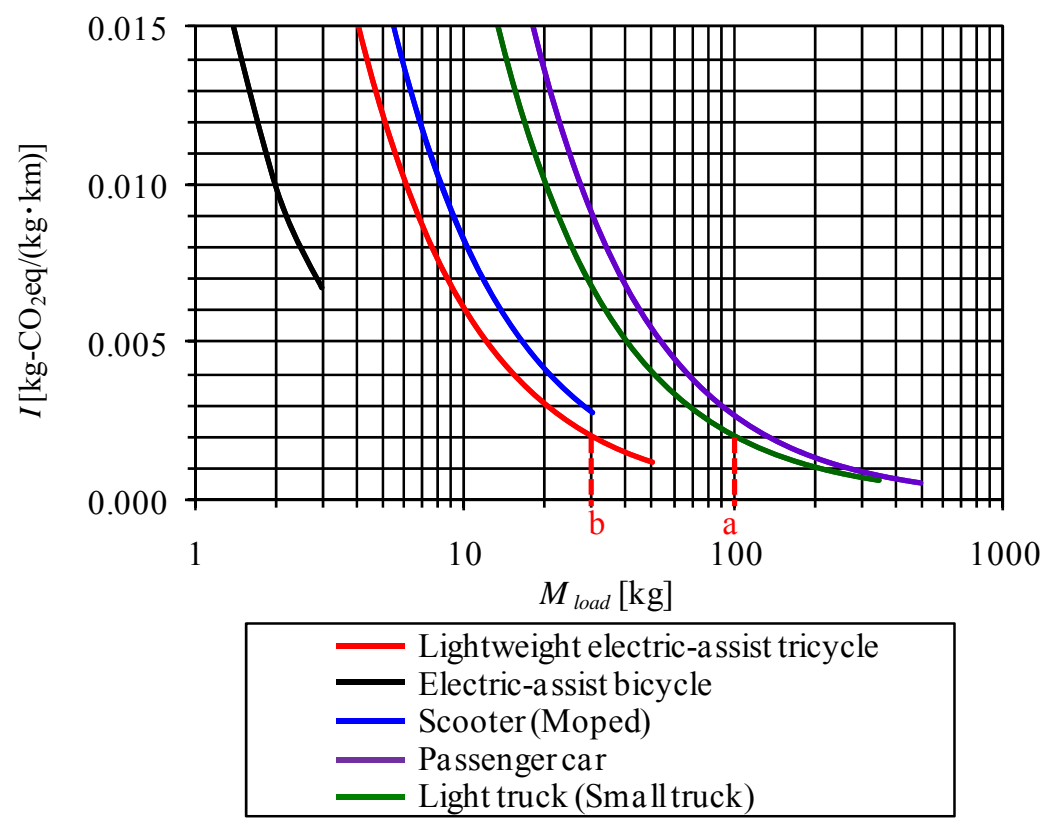

Fig. $9 \mathrm{CO}_{2}$ eq emission of each vehicle for unit transportation

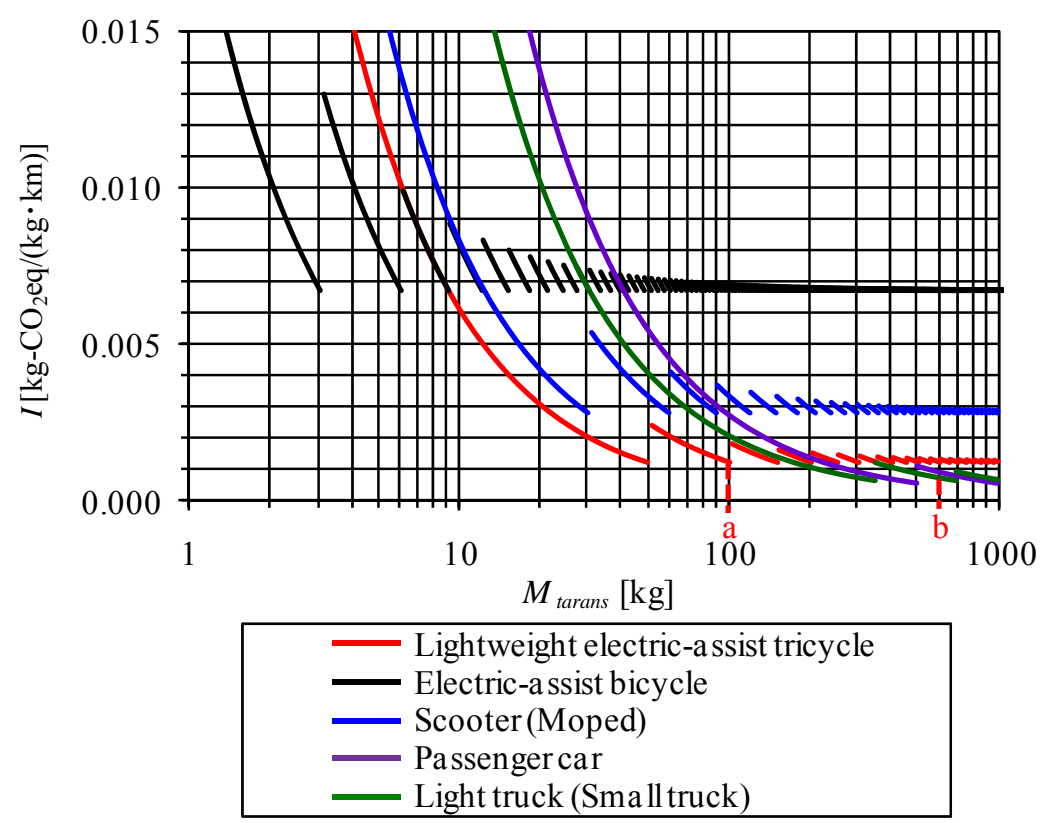

Fig. $10 \mathrm{CO}_{2}$ eq emission of each vehicle for unit transportation when loadage exceeds maximum capacity of each vehicle

\section{5. まとめ}

軽量電動アシストトライサイクルの材料調達, 製造, 運用ならびにリサイクル・廃棄に関するライフサイクル 環境評価を行うと共に，二酸化炭素等価排出量の観点から，軽量電動アシストトライサイクルの導入効果を既存 の輸送車両と比較検証した，ライフサイクル環境評価では，軽量電動アシストトライサイクルのエネルギー供給 源として太陽電池充電ポート供給，車載型燃料電池供給および買電供給について評価した。比較輸送車両は，軽 トラック，乗用車，スクーター，一般的な 2 輪電動アシスト自転車とした。

軽量電動アシストトライサイクルの環境評価について, 本研究で対象とした機器構成では, 太陽電池充電ポー トによる電力供給が最も二酸化炭素等価排出量が小さく, 順に買電供給, 車載型燃料電池供給と大きくなった. 車載型燃料電池供給に関しては，システムがプロトタイプということもあり，性能が十分発揮されていない点が 
考えられたままた，軽量電動アシストトライサイクルは，材料調達と製造における環境負荷が全体の環境負荷に 対して大きいことがわかった，そのため，環境負荷を考慮した材料を使用することの重要性が示唆された.

更に，軽量電動アシストトライサイクルと他の輸送車両との比較では，環境負荷が積載量や生涯走行距離に大 きく支配された．このため，各輸送車両での環境負荷への支配因子を示すと共に，任意の荷物を運搬する場合の 単位荷重単位距離あたりの二酸化炭素等価排出量を算出し, 荷物に適した運搬方法選定手法を提案した. その結 果，適切な積載量を確保することで，事業所内のような少量短距離輸送において軽量電動アシストトライサイク ル導入の有効性が示唆された，なお，本報では，ライフサイクル環境負荷低減に着目して評価を行った。環境負 荷低減の実現にはその対策費用も密接に関係するため, 今後，ライフサイクル環境負荷評価による課題抽出とそ の対策費用を連成して分析することが望まれる.

\section{謝 辞}

本研究は，経済産業省「低炭素社会に向けた技術シーズ発掘・社会システム実証モデル事業『“未来型自転車” をモデルとした次世代電池の研究開発・実証』」の一部で行われた. 本研究では, 軽量電動アシストトライサイク ルの車両製作に関して，CFRP 部品をはじめとする車両を設計製作した株式会社東京アールアンドデーにデータ を提供いただいた，走行実験および太陽電池充電ポートに関するデータ収集については，三菱化学株式会社にご 協力いただいた．車載型燃料電池の製作に関しては，BASF ジャパン株式会社および三重県工業研究所にデータ を提供いただいた。また，プロジェクト推進については，財団法人三重県産業支援センターに取り纒めていただ いた。ここに記して感謝の意を表する.

\section{文献}

(1) 紀伊雅敦, 湊清之, 廣田恵子, “トラック輸送効率化による CO2 削減効果のマクロ的分析”, 土木計画学研究・論 文集, Vol. 22, No. 4 (2005), pp. 761-766.

(2) 三洋電機株式会社, “太陽電池・充電池・電動ハイブリッド自転車で環境意識を啓蒙”, 三洋電機株式会社ニュース リリース, http://jp.sanyo.com/news/2009/03/18-1.html（参照日 2010 年 11 月 26 日）.

(3) 篠原亘, 島正樹, 平茂治, 松本光弘, 内橋健二, “アモルファスシリコン／薄膜結晶シリコン積層型太陽電池”, SANYO TECHNICAL REVIEW, Vol. 36, No. 2 (2004), pp. 34-42.

（4）中山浩，堀美知郎，“燃料電池の技術動向と将来”，電気製鋼，Vol. 77, No. 4 (2006), pp. 293-300.

(5) 吉村玄, 安保慧, 小野田弘士, 永田勝也, “未来型都市交通に対応したモビリティ機器の開発について”, 日本機械 学会第 19 回環境工学総合シンポジウム 2009 講演論文集, No. 9-13 (2009), pp. 485-488.

（6）鈴木克俊，湯村淳，関悠一郎，小野田弘士，永田勝也，“未来型都市交通に対応したモビリティ機器の開発とその 活用について”, 日本機械学会第 20 回環境工学総合シンポジウム 2010 講演論文集, No. 10-15 (2010), pp. 312-315.

(7) 高橋淳, “環境負荷低減を目指した複合材料技術の進展 3. CFRP の LCA と省エネルギー効果”, 材料 (Journal of the Society of Materials, Japan), Vol. 57, No. 8 (2008), pp. 852-855.

(8) 丸山直樹, 玉田充, “次世代電池を備えた複合素材軽量電動アシスト自転車の環境評価と導入効果”, 日本機械学会 第 20 回環境工学総合シンポジウム 2010 講演論文集, No. 10-15 (2010), pp. 306-309.

（9）財団法人日本規格協会，電動アシスト自転車一設計指針，JIS D9115:2009, p. 8.

(10) 環境省，経済産業省，“温室効果ガス排出量算定・報告マニュアル，第II編 温室効果ガス排出量の算定方法”, Ver. 3.1 (2010), p. 11.

(11) 環境省，経済産業省，“温室効果ガス総排出量算定方法ガイドライン”, (2007), p. 14.

(12) Larminie, J., and A. Dicks, A., 槌屋治紀 訳，解説 燃料電池システム（2004），p. 40，オーム社.

（13）原田幸明, “2．金属のリサイクルの現状”，金属材料のリサイクル， http://www.nims.go.jp/ecomaterial/my-library/recycle/M-recycle/M-RCYCL.htm（参照日 2010 年 10 月 26 日）.

（14）社団法人プラスチック処理促進協会, “2008 年プラスチック製品の生産・廃棄・再資源化・処理処分の状況”, (2009), p. 8 . 